\title{
Chemical soil fumigation for raspberry nursery in Jalisco (Mexico)
}

\author{
José M. López-Aranda ${ }^{\mathrm{a}, *}$, Francisco Gómez ${ }^{\mathrm{a}}$, Martín Puga ${ }^{\mathrm{a}}$, Ricardo Zamora $^{\mathrm{a}}$, Oleg Daugovish $^{\mathrm{b}}$ \\ and Marco A. Cotero ${ }^{\mathrm{a}}$ \\ a SEMARNAT/UNIDO, Plan Nacional de Eliminación del Bromuro de Metilo en México, Secretaría de Medio \\ Ambiente y Recursos Naturales (SEMARNAT), Col. Tlacopac, México, D.F. México \\ ${ }^{\mathrm{b}}$ Agriculture and Natural Resources, U.C. Cooperative Extension, University of California, Ventura, CA, USA
}

Received 27 July 2015; accepted 13 October 2015

\begin{abstract}
We evaluated the effectiveness of alternative fumigants on weed control, soil pests, plant growth and marketable roots production in a commercial nursery located at high-elevation and low latitude (Ciudad Guzman, Jalisco) during 2013 and 2014. Treatments were: Methyl bromide with chloropicrin (MB:CP); 1,3-dichloropropene:CP (1,3D:CP); CP alone; metam sodium (MS) alone; dimethyl disulphide with CP (DMDS:CP); and sequentially applied CP and MS (CP+MS). A Rotary Spading Machine was used for MS and CP followed by MS. All treatments except MS and CP+MS in 2014 controlled Rhizoctonia and all controlled Phytophthora in 2013, but none controlled Fusarium in soil. No significant nematode, Verticillium and Pythium populations were detected in nursery soil before treatments. No diseased plants were observed throughout the cultivation cycle. Densities and fresh weights of graminoid weeds were significantly reduced by MB:CP and $\mathrm{CP}+\mathrm{MS}$, but none of the fumigants controlled all forbs. Only Echinochloa crus-galli, Digitaria spp., Sonchus oleraceus, and Amaranthus hybridus densities and biomass were reduced $50-78 \%$ by all fumigants. The highest commercial yield of raspberry roots and plant emergence were recorded with $\mathrm{MB}: \mathrm{CP}$ and 1,3D:CP, while CP and MS only increased plant emergence. Finally, two years of work on MB alternatives were not sufficient to provide reliable recommendations on this critical need, therefore MBTOC recommended CUN for MB in 2015.
\end{abstract}

Keywords: Rubus idaeus, soil disinfestation, plant multiplication, methyl bromide, metam sodium, 1,3-dichloropropene, chloropicrin, dimethyl disulphide, weed control, yields

\section{Introduction}

Raspberry production in México is a dynamic and growing industry, where an increasingly important sector is the production of raspberry nursery stock. In 2013, there were more than 2,078 ha of raspberry fruit production in Mexico (1,511 ha in Jalisco, 290 ha in Michoacan and 229 ha in Baja California) (SAGARPA-Servicio de Información Agroalimentaria y Pesquera-SIAP) and production continues to expand. However, there are no official statistics for raspberry nursery acreage. It is estimated that there were approximately 310 ha in 2014 and 350 ha in 2015 of raspberry nureries. This represents the 230\% increase in acreage since 2009. The nurseries are located in several locations in Jalisco (Ciudad Guzman, Tapalpa and others) and Michoacan, with recent additional locations in Puebla State. Central Mexico (Michoacán and Jalisco) grows "off-season" plants at low

\footnotetext{
${ }^{*}$ Corresponding author: José M. López-Aranda, SEMARNAT/UNIDO, Plan Nacional de Eliminación del Bromuro de Metilo en México. Secretaría de Medio Ambiente y Recursos Naturales (SEMARNAT), Col. Tlacopac, México, D.F. México. E-mail: jmlaranda@gmail.com.
} 
latitude $\left(19 / 20^{\circ} \mathrm{N}\right.$ parallel) and has nurseries at high-elevation areas (1,600 to 2,000 $\mathrm{m}$ above sea level) to produce the plant material for strawberry and caneberries [1,2].

Very few studies have been published on soil fumigation for raspberry nurseries in international journals. Raspberry nurseries must produce disease-free plants to meet marketplace, certification and export requirements. Nursery phytosanitary requirements are high, because even minor disease infestations in nurseries can cause severe epidemics in production fields. Historically, transplants for Mexican raspberry production have been purchased from California, but due to the rapidly growing Mexican nursery sector, more and more fruit producers are able to obtain their planting stock in México. Nursery fields are fumigated during November and December in Mexico. The mother plants (roots) are transplanted during February. Raspberry roots are harvested during the following December to late-February, to be transplanted into production fields a few months later, starting in May. Rotations with cereals (sorghum and corn) and pasture land are common with three to five year interval between raspberry nursery plantings.

Soil-borne fungal pathogens (such as Phytophthora spp., Verticillium spp., Rhizoctonia spp., Pythium spp., and Fusarium spp.), crown gall (Agrobacterium tumefasciens), root lesion nematode (Pratylenchus penetrans) and weeds are common pests of Mexican strawberry and raspberry nurseries. Phytophthora root rot caused by $P$. fragariae var. rubi is the most serious root disease of red raspberries in many growing regions (Walters, pers.com.). Raspberry roots are also very sensitive to excessive moisture and lack of oxygen in the soil for extended periods of time. These conditions cause decay and root death [3-5].

Best roots are produced in non-infested soils with good drainage. The use of raised beds and proper irrigation management can improve drainage and aeration of roots, thus, reducing disease incidence and severity. Pre-plant fumigation can reduce initial disease inoculum and allow plant establishment in heavily infected sites, though the pathogen will often recolonize the site with time [5].

The application of methyl bromide (MB) in raspberry nurseries is recent in Mexico, but MB has been classified as an ozone depleting substance and has been banned in all countries of Montreal Protocol (MP) with the exception of possible critical use exemptions (CUE) [6-8]. In Mexico commercially-available alternatives to MB are CP alone, MS, MK, dazomet, 1,3-dichloropropene (1,3-D), and 1,3-D:CP mixture and, recently, dimethyl disulphide (DMDS), alone and/or in combination with CP (cofepris.gob.mx). Soil fumigation with 1,3-D:CP, CP and MS are the most widespread chemical solutions for strawberry fruit and nursery production in conventional areas of production in the world [9]. DMDS alone or in combination with CP, MS and/or dazomet have been evaluated for strawberry nursery in Spain since 2002 [10-13], but never for raspberry nursery. The challenge for MB alternatives is to maintain commercial root yields and quality at the level of MB. So far, no specific research has been conducted on soil fumigation and MB alternatives for raspberry nurseries in Mexico; and very few articles have been presented in peer-reviewed publications on this topic.

Appropriate viable alternatives to MB are necessary for raspberry nurseries in Mexico currently and in the long term. Our objectives were: a) to identify alternative soil disinfestations treatments that control soil-borne pests and weeds and produce commercial root yields similar to MB treatment; and b) to carry forward the most promising treatments to commercial-scale evaluations. Preliminary results in 2010-2013 were previously published [2].

\section{Materials and methods}

Fumigation trials were conducted in 2013 and 2014 at the high-elevation Driscoll's nursery (Rancho La Autopista) located in Ciudad Guzmán (Jalisco, Mexico) (1,560 m above sea level and latitude $19^{\circ} 41^{\prime} \mathrm{N}$ ). Trials were conducted in replicated experiments. The nursery was never fumigated before; the cropping history was a rotation of corn with sorghum.

Mother plant roots of cv. 'Maravilla' were planted in each replicated experimental trial. Standard cultural practices for commercial root plants production were followed (Infante, pers.com.). Replicated plot experiments 
Table 1

Fumigation treatments in 2013 and 2014

\begin{tabular}{|c|c|c|c|}
\hline Treatment & Application methods and rates & 2013 & 2014 \\
\hline T0 No trat. & Non-fumigated & No & Yes \\
\hline T1 (MB:CP) & Broadcast (flat) shank-applied, $400 \mathrm{~kg} / \mathrm{ha}(50 / 50 \mathrm{w} / \mathrm{w})$, transparent HDPE tarp & Yes & Yes \\
\hline $\mathrm{T} 2(1,3 \mathrm{D}: \mathrm{CP})$ & $\begin{array}{l}\text { Broadcast (flat) shank-applied, } 400 \mathrm{~kg} / \mathrm{ha}(65 / 35 \mathrm{w} / \mathrm{w})\left(\text { commercial product Piclor }^{\circledR}\right) \text {, transparent } \\
\text { HDPE tarp }\end{array}$ & Yes & Yes \\
\hline $\mathrm{T} 3(\mathrm{CP})$ & Broadcast (flat) shank-applied, $400 \mathrm{~kg} / \mathrm{ha}(100 \% \mathrm{CP})$, transparent HDPE tarp & Yes & Yes \\
\hline $\mathrm{T} 4(\mathrm{CP}+\mathrm{MS})$ & $\begin{array}{l}\text { Sequential applied broadcast (flat) shank-applied CP ( } 250 \mathrm{~kg} / \mathrm{ha} \text { ) transparent HDPE tarp followed by } \\
\text { Rotary Spader (working width of } 2.25 \mathrm{~m}) \mathrm{MS}(500 \mathrm{l} / \mathrm{ha})\end{array}$ & Yes & Yes \\
\hline T5 (MS) & Broadcast (flat) injected with Rotary Spader (1000 1/ha) & Yes & Yes \\
\hline T6 (DMDS:CP) & Broadcast (flat) shank-applied, 281 1/ha Paladin ${ }^{\circledR}(79 / 21 \mathrm{w} / \mathrm{w})$, transparent TIF tarp & No & Yes \\
\hline
\end{tabular}

Cv. 'Driscoll Maravilla' in 2013 and 2014.

were in sandy loams soils with $\mathrm{pH}$ of 5.4-6.3 and 1.9-2.4\% organic matter. Fumigation treatments, rates and methods of application at each site are listed in Table 1. Treatments (five in 2013 and seven in 2014) were arranged in a randomized complete block design with four replicates per treatment in 2013 and seven replicates per treatment in 2014. Fumigant treatments were applied during the second half of December 2012 and midJanuary 2014. Commercial raspberry roots were harvested during the first week of January in 2014 and 18 to 20 December in 2014. Individual plots were $162.5 \mathrm{~m}^{2}$ in 2013 and $600 \mathrm{~m}^{2}$ in 2014.

Each season, plants (raspberry roots) were planted in a double rows in $1.20 \mathrm{~m}$ wide beds separated by $0.5 \mathrm{~m}$ wide furrows. Plants were placed $0.30 \mathrm{~m}$ from the edges of the beds at the rate of $500 \mathrm{~kg} / \mathrm{ha}$. Plants were irrigated as needed by sprinkler with $10 \mathrm{~m}$ spacing between heads in all directions. The dates of planting were March 13 , 2013 and March 18-19, 2014.

To quantify the soil fungal populations, the levels of soil-borne fungi in each plot of replicated plots were estimated as colony forming units (CFU) $\mathrm{g}^{-1}$ dry soil, before (December, 6, 2012 and January 10, 2014) and after fumigant treatments (February, 10, 2013 and February, 10, 2014) (Table 2). Prior to treatment application five soil samples from the whole nursery were randomly taken in a zigzagged pattern from the $0-15 \mathrm{~cm}$ depth and mixed to make composite samples. All soil samples were dried at room temperature in open bags and then passed through a 10.0-mm-mesh sieve. Then samples were shipped to specialized laboratory to estimate colony forming units (CFU) $\mathrm{g}^{-1}$ dry soil, on Potato-dextrose agar medium (PDAs), and selective media for Fusarium spp., Pythium spp., Verticillium spp., Phytophthora spp. and Rhizoctonia spp., following methodology described by $\mathrm{De} \mathrm{Cal}$ et al. $[10,11]$. The same soil samples were also used to determine nematode populations before and after fumigation treatments following sieving/centrifugation methodology described by Jenkins [14].

Before planting in 2014, 50 raspberry mother plants of cv. 'Driscoll Maravilla' were randomly selected from the total amount of plants to be used in the experimental fields to evaluate their sanitary status. These mother plants were grown in MB:CP fumigated Driscoll's Mexican nursery. The plants were transferred to humid chambers and the presence/absence of fungal pathogens on the plants was determined and species identified following methodology described by De Cal et al. [10].

Raspberry disease incidence in each plot and year was recorded three times after transplanting throughout the season in 2013 and five times in 2014. Twenty raspberry plants in the central part of the beds of each plot were sampled on May 20, June 20 and July 15, 2013 and April, 8, May 8, July 10, August 6 and November 27, 2014. The plants were examined visually and the number of plants with external disease symptoms (e.g. collapse, wilt, rot, necrosis, etc.) was recorded. These plants were taken to the laboratory to determine casual agents as described previously for raspberry mother plants in 2014. The incidence of diseased plants was calculated as the percentage of symptomatic plants in the twenty samples in each plot and date. Also, the incidence of the scarab beetles in the subfamily Melolonthinae, Phyllophaga sp. genus (June Bug, Gallina ciega), in each plot and year 
Table 2

Fungal populations (CFU g ${ }^{-1}$ dry weight of soil) before and alter fumigation treatments in 2013 and 2014

\begin{tabular}{|c|c|c|c|c|c|c|c|c|c|c|}
\hline \multirow[t]{2}{*}{ Treatment } & \multicolumn{2}{|c|}{ Fusarium } & \multicolumn{2}{|c|}{ Verticillium } & \multicolumn{2}{|c|}{ Pythium } & \multicolumn{2}{|c|}{ Rhizoctonia } & \multicolumn{2}{|c|}{ Phytophthora } \\
\hline & Before & After & Before & After & Before & After & Before & After & Before & After \\
\hline \multicolumn{11}{|c|}{2013 Replicated plot experiments } \\
\hline T1 (BM:CP) & 50 & $96.25 \mathrm{a}$ & 0 & $0 \mathrm{a}$ & 0 & $21.50 \mathrm{a}$ & 25 & $0 \mathrm{a}$ & 50 & $0 \mathrm{a}$ \\
\hline $\mathrm{T} 2$ (1,3D:CP) & 50 & $121.75 \mathrm{a}$ & 0 & $0 \mathrm{a}$ & 0 & $121.75 \mathrm{a}$ & 25 & $0 \mathrm{a}$ & 50 & $0 \mathrm{a}$ \\
\hline $\mathrm{T} 3(\mathrm{CP})$ & 50 & $21.50 \mathrm{a}$ & 0 & $0 \mathrm{a}$ & 0 & $7.50 \mathrm{a}$ & 25 & $0 \mathrm{a}$ & 50 & $0 \mathrm{a}$ \\
\hline $\mathrm{T} 4(\mathrm{CP}+\mathrm{MS})$ & 50 & $146.50 \mathrm{a}$ & 0 & $0 \mathrm{a}$ & 0 & $21.50 \mathrm{a}$ & 25 & $0 \mathrm{a}$ & 50 & $0 \mathrm{a}$ \\
\hline T5 (MS) & 50 & $177.75 \mathrm{a}$ & 0 & $0 \mathrm{a}$ & 0 & $180.75 \mathrm{a}$ & 25 & $0 \mathrm{a}$ & 50 & $0 \mathrm{a}$ \\
\hline \multicolumn{11}{|c|}{2014 Replicated plot experiments } \\
\hline T0 Untreated & 250 & $105.00 \mathrm{c}$ & 0 & Ob & 0 & $0 \mathrm{~b}$ & 66 & $0 \mathrm{~b}$ & 50 & $61.00 \mathrm{a}$ \\
\hline T1 (BM:CP) & 250 & $38.57 \mathrm{c}$ & 0 & $0 \mathrm{~b}$ & 0 & $0 \mathrm{~b}$ & 66 & $0 \mathrm{~b}$ & 50 & $8.57 \mathrm{a}$ \\
\hline $\mathrm{T} 2$ (1,3D:CP) & 250 & $91.71 \mathrm{c}$ & 0 & $20.29 b$ & 0 & $0 \mathrm{~b}$ & 66 & $0 \mathrm{~b}$ & 50 & $32.14 \mathrm{a}$ \\
\hline $\mathrm{T} 3(\mathrm{CP})$ & 250 & $54.71 \mathrm{c}$ & 0 & $4.29 b$ & 0 & $0 \mathrm{~b}$ & 66 & $0 \mathrm{~b}$ & 50 & $46.00 \mathrm{a}$ \\
\hline $\mathrm{T} 4(\mathrm{CP}+\mathrm{MS})$ & 250 & $237.29 b$ & 0 & $82.43 \mathrm{a}$ & 0 & $37.43 \mathrm{a}$ & 66 & $21.29 \mathrm{ab}$ & 50 & $0 \mathrm{a}$ \\
\hline T5 (MS) & 250 & $380.00 \mathrm{a}$ & 0 & $32.14 \mathrm{ab}$ & 0 & $21.43 \mathrm{ab}$ & 66 & $26.57 \mathrm{a}$ & 50 & $37.43 \mathrm{a}$ \\
\hline T6 (DMDS:CP) & 250 & $74.57 \mathrm{c}$ & 0 & $0 \mathrm{~b}$ & 0 & $0 \mathrm{~b}$ & 66 & $0 \mathrm{~b}$ & 50 & $55.71 \mathrm{a}$ \\
\hline
\end{tabular}

Treatments followed by the same letter within a column are not significantly different according to the LSD test $(P<0.05)$.

was recorded twice during each season: in July and at the end of September. One soil sample ( $2 \mathrm{~kg})$ was taken in the central part on each replication at $30 \mathrm{~cm}$ depth. Each sample was carefully examined on worktable for presence or absence of Phyllophaga sp. beetles.

To monitor weed populations, sample quadrats were placed in each plot for the duration of each season of cultivation. There were two $6.5 \mathrm{~m}^{2}$ quadrats per replicate in 2013 and one $15 \mathrm{~m}^{2}$ per replicate in 2014 . Weeds in the sample quadrats were collected on five (2013) and seven (2014) dates from mid-April until mid-October, 2013 and from mid-February (before planting) until end of September, 2014. At each sampling date weed species were identified, counted to determine weed densities by species, and removed with roots to determine total fresh weights.

To monitor the growth of raspberry plants the height of ten plants in the central part of the bed in each plot was measured three times (May, 21, June, 24 and July, 22) in 2013 and four times (April, 29, June, 5, July, 29 and November, 28) in 2014. Additionally, plant emergence was monitored in 2014. The number of raspberry plants emerged on three different dates (April, 24, May, 21 and June, 20) in 2014 was recorded in two different sections of the beds ( $2 \mathrm{~m}$ long each). The plants were machine-harvested from the replicated experiments: first, pruned above-ground and then the roots were excavated. The removal of above-ground parts was carried out with rotovators during the day. The roots were harvested during the night (using plant diggers), loaded and delivered to sorting sheds in plastic "pallets" by refrigerated trucks. Trained crews sorted and weighed marketable roots for each plot and replication.

The processing of the commercial roots included: pressurized washing with water, hand-cleaning, spray application with standard fungicides (e.g., iprodione) and packing in $12 \mathrm{~kg}$-capacity carton boxes. There are no official criteria for raspberry roots quality after harvest in nursery. For this reason, we followed standards given by the nursery owners (Infante, pers. com.). During sorting all thick lignified roots without adventitious buds and remainders of crown were eliminated. Also, in 2014 prior to machine-harvesting, plants from three randomly selected $1 \mathrm{~m}^{2}$ areas in the central part of each plot were harvested by hand and processed as described previously. Commercial root weights harvested inside these three areas were recorded. 
Data for fungal and nematode populations, symptomatic plants, emergence and growth of plants, weed densities, fresh weed weights and root yields were subjected to a two-way analysis of variance (ANOVA) using the STATISTIX 8.0 program (Analytical Software, Ltd., La Jolla, CA, USA). Significant differences were considered at the 5\% probability level unless otherwise stated. When significant differences were found, Fisher's least significant difference (LSD) test was used to compare mean values.

\section{Results and discussion}

Soil fungal populations before and after fumigation treatments are shown in Table 2. All treatments except MS and CP+MS in 2014 controlled Rhizoctonia and all controlled Phytophthora in 2013. Phytophthora root rot is an important disease caused by several species of Phytophthora, the most dangerous and common in caneberries is P. fragariae var. rubi. Phytophthora root rot is commonly found in soils that remain saturated for periods of time, such as in low areas with clay soils or near leaking irrigation lines [15], but it was not the case for soils in the trials at "La Autopista" nursery. Soil fumigation with 1,3D:CP (Telone C-35 commercial product), similar to our T2 (1,3D:CP) treatment is commonly used to control Phytophthora populations [5]. Fusarium populations (F. solani, F. subglutinans, F. equiseti, F. oxysporum), were not reduced in replicated plot experiments in 2014 (Table 2). Pythium spp. and Verticillium albo-atrum were detected at extremely low levels before and after treatments. In California, Verticillium wilt caused by V. dahliae is rarely found in raspberries but it can be a difficult disease to manage [5]. Verticillium wilt management includes avoidance of fields with recent crop history of highly susceptible vegetable crops [5], but that was not the case for these experiments in Mexico. However, fields that have been infested with weeds that are hosts of Verticillium spp. such as pigweed (Amaranthus spp.), nightshades (Solanum spp.), and lambsquarters (Chenopodium album) can also contain high levels of the fungal microsclerotia [5]. Soil fumigation with 1,3D:CP (Telone C-35 commercial product), similar to our T2 (1,3D:CP) and with CP (NutraPic commercial product) similar to our T3 (CP) treatment are commonly used to control Verticillium wilt [5].

In 2013, small populations of non-pathogenic nematodes (Criconemoides, Tylenchorhynchus, Paratylenchus and Aphelenchus genera) were detected before and after treatments. Only small nematode populations (Aphelenchus) were detected in 2013 after treatments: 0 (in T1 (BM:CP) and T4 (CP+MS)), 9.00 in T3 (CP) and 19.25 in T2 (1,3D:CP) for individuals per $100 \mathrm{~g}$ dry weight of soil, with no significant differences $(P<0.05)$ among treatments.

Analysis of a sample of mother plants in 2014 (cv. 'Driscoll Maravilla') before planting showed presence of fungal pathogens such as $F$. solani, $R$. solani and Pythium spp. in roots and F. solani and Alternaria spp. in leaves; however, no presence of pathogenic bacteria was detected in the plant samples (data not shown).

Generally, no diseased plants were observed throughout the cultivation cycles. The exception was a single plant in 2013 in T4 (CP+MS) with presence of F. solani, Cercospora sp., Colletotrichum sp., and Alternaria sp.

Twenty one weed species were observed in the study of which seven were present in all locations and years: barnyardgrass (zacate de agua) (Echinochloa crus-galli), bermudagrass (grama) (Cynodon dactylon), Canadian horseweed (cola de caballo) (Conyza canadensis), burcucumber (chayotillo) (Sicyos angulata), roundleaf geranium (cilantrillo) (Geranium rotundifolium), crabgrasses (zacate fresadillo) (Digitaria spp.), and common sowthistle (borraja) (Sonchus oleraceus). Only weed densities and biomass of Echinochloa crus-galli, Digitaria spp., Sonchus oleraceus, and Amaranthus hybridus were significantly reduced by treatments (Table 3).

Weed life cycles (annual and/or perennial) were classified in two main categories following USDA Plant Database criteria (graminoids and forbs) [16]. Graminoids included six species: Cynodon dactylon, Digitaria spp., Echinochloa crus-galli, tufted lovegrass (zacate estrella) Eragrostis pectinacea, sorghum (zacate milpilla) (Sorghum bicolor), and corn (maíz) Zea mays. The 15 forb species were: Spanish needles (aceitilla) Bidens pilosa, Conyza bonariensis, Conyza canadensis, little mallow (malva) Malva parviflora, Sonchus oleraceus, cutleaf groundcherry (tomatillo) Physalis angulata, Lepidium sp., lambsquarters (quelite cenizo) Chenopodium album, 
Table 3

Weed densities and fresh weights for main weeds species

\begin{tabular}{|c|c|c|c|c|}
\hline & \multicolumn{2}{|c|}{2013} & \multicolumn{2}{|c|}{2014} \\
\hline & $\mathrm{Wt}\left(\mathrm{g} / \mathrm{m}^{2}\right)$ & $\mathrm{Num} / \mathrm{m}^{2}$ & Wt $\left(\mathrm{g} / \mathrm{m}^{2}\right)$ & $\mathrm{Num} / \mathrm{m}^{2}$ \\
\hline \multicolumn{5}{|c|}{ Barnyardgrass (Zacate de agua) (Echinochloa crus-galli) } \\
\hline T0 untreat. & - & - & $99.3 \mathrm{ab}$ & $1.8 \mathrm{a}$ \\
\hline T1 (MB:CP) & $15.5 b$ & $0.2 \mathrm{a}$ & $1.6 \mathrm{~b}$ & $0.1 b$ \\
\hline $\mathrm{T} 2$ (1,3D:CP) & $76.3 \mathrm{ab}$ & $0.6 \mathrm{a}$ & $19.8 \mathrm{~b}$ & $0.2 b$ \\
\hline $\mathrm{T} 3(\mathrm{CP})$ & $108.9 \mathrm{a}$ & $1.9 \mathrm{a}$ & $38.8 \mathrm{ab}$ & $0.6 b$ \\
\hline $\mathrm{T} 4(\mathrm{CP}+\mathrm{MS})$ & $13.8 \mathrm{~b}$ & $0.3 \mathrm{a}$ & $10.4 \mathrm{~b}$ & $0.1 b$ \\
\hline T5 (MS) & $40.4 \mathrm{ab}$ & $0.2 \mathrm{a}$ & $20.1 b$ & $0.3 b$ \\
\hline T6 (DMDS:CP) & - & - & $127.5 \mathrm{a}$ & $0.9 \mathrm{ab}$ \\
\hline \multicolumn{5}{|c|}{ Crabgrasses (Zacate fresadillo) (Digitaria spp.) } \\
\hline T0 untreat. & - & - & $513.2 \mathrm{a}$ & $16.1 \mathrm{a}$ \\
\hline T1 (MB:CP) & $27.5 \mathrm{c}$ & $1.6 \mathrm{c}$ & $3.4 \mathrm{c}$ & $0.2 b$ \\
\hline $\mathrm{T} 2$ (1,3D:CP) & $158.5 \mathrm{a}$ & $8.8 \mathrm{a}$ & $16.1 \mathrm{c}$ & $0.3 b$ \\
\hline $\mathrm{T} 3(\mathrm{CP})$ & $161.9 \mathrm{a}$ & $10.3 \mathrm{a}$ & $75.8 \mathrm{c}$ & $1.4 \mathrm{~b}$ \\
\hline $\mathrm{T} 4(\mathrm{CP}+\mathrm{MS})$ & $39.8 \mathrm{bc}$ & $1.7 \mathrm{c}$ & $79.5 \mathrm{bc}$ & $2.2 b$ \\
\hline T5 (MS) & 129.0ab & $6.4 \mathrm{~b}$ & $24.1 \mathrm{c}$ & $1.3 b$ \\
\hline T6 (DMDS:CP) & - & - & $379.6 \mathrm{ab}$ & $7.2 \mathrm{ab}$ \\
\hline \multicolumn{5}{|c|}{ Common sowthistle (Borraja) (Sonchus oleraceus) } \\
\hline T0 untreat. & - & - & $107.8 \mathrm{a}$ & $5.7 \mathrm{a}$ \\
\hline T1 (MB:CP) & $2.5 \mathrm{a}$ & $0.20 \mathrm{a}$ & $47.1 \mathrm{~b}$ & $2.0 \mathrm{bc}$ \\
\hline $\mathrm{T} 2$ (1,3D:CP) & $4.0 \mathrm{a}$ & $0.10 \mathrm{a}$ & $21.7 b$ & $1.5 \mathrm{c}$ \\
\hline $\mathrm{T} 3(\mathrm{CP})$ & $9.6 \mathrm{a}$ & $0.20 \mathrm{a}$ & $35.1 \mathrm{~b}$ & $1.6 \mathrm{c}$ \\
\hline $\mathrm{T} 4(\mathrm{CP}+\mathrm{MS})$ & $10.4 \mathrm{a}$ & $0.90 \mathrm{a}$ & $51.4 \mathrm{~b}$ & $2.0 \mathrm{bc}$ \\
\hline T5 (MS) & $7.3 \mathrm{a}$ & $0.30 \mathrm{a}$ & $106.9 \mathrm{a}$ & $3.9 \mathrm{ab}$ \\
\hline T6 (DMDS:CP) & - & - & $50.9 \mathrm{~b}$ & $2.2 \mathrm{bc}$ \\
\hline \multicolumn{5}{|c|}{ Canadian horseweed (Cola de caballo) (Conyza canadensis) } \\
\hline T0 untreat. & - & - & $31.1 \mathrm{a}$ & $1.3 \mathrm{a}$ \\
\hline T1 (MB:CP) & $5.0 \mathrm{a}$ & $0.40 \mathrm{a}$ & $14.1 \mathrm{ab}$ & $1.3 \mathrm{a}$ \\
\hline $\mathrm{T} 2(1,3 \mathrm{D}: \mathrm{CP})$ & $1.2 \mathrm{a}$ & $0.20 \mathrm{a}$ & $13.0 \mathrm{~b}$ & $0.7 \mathrm{a}$ \\
\hline $\mathrm{T} 3(\mathrm{CP})$ & $3.1 \mathrm{a}$ & $0.40 \mathrm{a}$ & $13.8 \mathrm{ab}$ & $1.0 \mathrm{a}$ \\
\hline $\mathrm{T} 4(\mathrm{CP}+\mathrm{MS})$ & $1.7 \mathrm{a}$ & $0.30 \mathrm{a}$ & $10.2 b$ & $0.9 \mathrm{a}$ \\
\hline T5 (MS) & $4.6 \mathrm{a}$ & $0.40 \mathrm{a}$ & $20.0 \mathrm{ab}$ & $1.2 \mathrm{a}$ \\
\hline T6 (DMDS:CP) & - & - & $10.2 b$ & $1.0 \mathrm{a}$ \\
\hline \multicolumn{5}{|c|}{ Burcucumber (Chayotillo) (Sicyos angulata) } \\
\hline T0 untreat. & - & - & 284.1a & $2.4 \mathrm{a}$ \\
\hline T1 (MB:CP) & $102.3 \mathrm{a}$ & $3.1 \mathrm{a}$ & $61.1 \mathrm{~b}$ & $0.7 \mathrm{~b}$ \\
\hline $\mathrm{T} 2$ (1,3D:CP) & $157.3 \mathrm{a}$ & $4.2 \mathrm{a}$ & $109.1 b$ & $1.9 \mathrm{ab}$ \\
\hline $\mathrm{T} 3(\mathrm{CP})$ & $105.3 \mathrm{a}$ & $3.7 \mathrm{a}$ & $62.1 \mathrm{~b}$ & $0.9 \mathrm{~b}$ \\
\hline $\mathrm{T} 4(\mathrm{CP}+\mathrm{MS})$ & $69.8 \mathrm{a}$ & $3.9 \mathrm{a}$ & $94.9 \mathrm{~b}$ & $1.0 \mathrm{ab}$ \\
\hline T5 (MS) & $188.0 \mathrm{a}$ & $3.3 \mathrm{a}$ & $43.2 b$ & $0.5 \mathrm{~b}$ \\
\hline T6 (DMDS:CP) & - & - & $159.0 \mathrm{ab}$ & $1.6 \mathrm{ab}$ \\
\hline
\end{tabular}


Table 3

(Continued)

\begin{tabular}{|c|c|c|c|c|}
\hline & \multicolumn{2}{|c|}{2013} & \multicolumn{2}{|c|}{2014} \\
\hline & Wt $\left(\mathrm{g} / \mathrm{m}^{2}\right)$ & $\mathrm{Num} / \mathrm{m}^{2}$ & Wt $\left(\mathrm{g} / \mathrm{m}^{2}\right)$ & $\mathrm{Num} / \mathrm{m}^{2}$ \\
\hline \multicolumn{5}{|c|}{ Roundleaf geranium (Cilantrillo) (Geranium rotundifolium) } \\
\hline T0 untreat. & - & - & $10.9 \mathrm{~b}$ & $1.8 \mathrm{~b}$ \\
\hline T1 (MB:CP) & $0.4 \mathrm{~b}$ & $0.04 \mathrm{a}$ & $103.3 \mathrm{ab}$ & $6.1 b$ \\
\hline $\mathrm{T} 2$ (1,3D:CP) & $0.0 \mathrm{~b}$ & $0.00 \mathrm{a}$ & $85.6 \mathrm{ab}$ & $26.4 \mathrm{ab}$ \\
\hline $\mathrm{T} 3(\mathrm{CP})$ & $1.5 \mathrm{~b}$ & $0.02 \mathrm{a}$ & $9.0 \mathrm{~b}$ & $1.5 \mathrm{~b}$ \\
\hline $\mathrm{T} 4(\mathrm{CP}+\mathrm{MS})$ & $6.3 \mathrm{a}$ & $0.08 \mathrm{a}$ & $307.0 \mathrm{a}$ & $46.9 \mathrm{a}$ \\
\hline T5 (MS) & $3.7 \mathrm{ab}$ & $0.10 \mathrm{a}$ & $58.1 \mathrm{ab}$ & $5.6 b$ \\
\hline T6 (DMDS:CP) & - & - & $124.1 \mathrm{ab}$ & $17.3 \mathrm{ab}$ \\
\hline \multicolumn{5}{|c|}{ Tree tobacco (Gigantecimarrón) (Nicotiana glauca) } \\
\hline T0 untreat. & - & - & $6.0 \mathrm{c}$ & $2.2 \mathrm{c}$ \\
\hline T1 (MB:CP) & $1.2 \mathrm{~b}$ & $0.1 b$ & $42.3 \mathrm{c}$ & $7.9 \mathrm{c}$ \\
\hline $\mathrm{T} 2(1,3 \mathrm{D}: \mathrm{CP})$ & $1.3 \mathrm{~b}$ & $0.4 \mathrm{~b}$ & $191.3 \mathrm{a}$ & $32.1 \mathrm{a}$ \\
\hline $\mathrm{T} 3(\mathrm{CP})$ & $15.4 \mathrm{a}$ & $1.3 \mathrm{a}$ & $6.1 \mathrm{c}$ & $2.1 \mathrm{c}$ \\
\hline $\mathrm{T} 4(\mathrm{CP}+\mathrm{MS})$ & $1.0 \mathrm{~b}$ & $0.1 \mathrm{~b}$ & $148.3 \mathrm{ab}$ & $24.4 \mathrm{ab}$ \\
\hline T5 (MS) & $0.0 \mathrm{~b}$ & $0.0 \mathrm{~b}$ & $7.9 \mathrm{c}$ & $0.9 \mathrm{c}$ \\
\hline T6 (DMDS:CP) & - & - & $118.6 \mathrm{bc}$ & $19.7 b$ \\
\hline \multicolumn{5}{|c|}{ Hairy fleabane (Rama negra) (Conyzabonariensis) } \\
\hline T0 untreat. & - & - & $90.4 b$ & $2.9 \mathrm{a}$ \\
\hline T1 (MB:CP) & $3.1 \mathrm{a}$ & $0.40 \mathrm{a}$ & $124.8 \mathrm{~b}$ & $2.3 \mathrm{a}$ \\
\hline $\mathrm{T} 2$ (1,3D:CP) & $8.7 \mathrm{a}$ & $0.30 \mathrm{a}$ & $149.0 \mathrm{~b}$ & $2.7 \mathrm{a}$ \\
\hline $\mathrm{T} 3(\mathrm{CP})$ & $3.1 \mathrm{a}$ & $0.20 \mathrm{a}$ & $23.0 \mathrm{c}$ & $0.6 \mathrm{a}$ \\
\hline $\mathrm{T} 4(\mathrm{CP}+\mathrm{MS})$ & $0.4 \mathrm{a}$ & $0.06 \mathrm{a}$ & $258.7 \mathrm{a}$ & $5.5 \mathrm{a}$ \\
\hline T5 (MS) & $2.1 \mathrm{a}$ & $0.30 \mathrm{a}$ & $25.8 \mathrm{c}$ & $0.7 \mathrm{a}$ \\
\hline T6 (DMDS:CP) & - & - & $263.5 \mathrm{a}$ & $5.6 \mathrm{a}$ \\
\hline \multicolumn{5}{|c|}{ Smooth pigweed (Quelitebledo) (Amaranthus hybridus) } \\
\hline T0 untreat. & - & - & $89.1 \mathrm{a}$ & $1.90 \mathrm{a}$ \\
\hline T1 (MB:CP) & 0 & 0 & $0.1 \mathrm{~b}$ & $0.01 b$ \\
\hline $\mathrm{T} 2(1,3 \mathrm{D}: \mathrm{CP})$ & 0 & 0 & $35.6 \mathrm{ab}$ & $0.05 b$ \\
\hline $\mathrm{T} 3(\mathrm{CP})$ & 0 & 0 & $0.7 \mathrm{~b}$ & $0.05 b$ \\
\hline $\mathrm{T} 4(\mathrm{CP}+\mathrm{MS})$ & 0 & 0 & $0.5 b$ & $0.01 \mathrm{~b}$ \\
\hline T5 (MS) & 0 & 0 & $0.0 \mathrm{~b}$ & $0.00 \mathrm{~b}$ \\
\hline T6 (DMDS:CP) & - & - & $1.1 \mathrm{~b}$ & $0.01 \mathrm{~b}$ \\
\hline
\end{tabular}

Treatments followed by the same letter within a column (for each weed) are not significantly different according to the LSD test $(P<0.05)$.

common purslane (verdolaga) Portulaca oleracea, Mexican pricklypoppy (chicalote) Argemone mexicana, Sicyos angulata, roundleaf geranium (cilantrillo) Geranium rotundifolium, smooth pigweed (quelite bledo) Amaranthus hybridus, tall morningglory (campanilla) Ipomoea purpurea, and the shrub tree type of tree tobacco (gigante cimarrón) Nicotiana glauca.

Numbers and fresh weights of graminoids were significantly reduced by MB:CP and CP+MS compared to CP alone in 2013 and by all fumigant treatments compared to untreated in 2014 (Table 4). In general, all treatments failed to control forbs, with exception of $\mathrm{CP}$ alone in 2014 that reduced biomass of forbs $86 \%$ compared to 
Table 4

Total weed densities and fresh weights in 2013 and 2014

\begin{tabular}{|c|c|c|c|c|c|c|}
\hline \multirow[t]{2}{*}{ Treatments } & \multicolumn{3}{|c|}{ Fresh weight $\left(\mathrm{g} / \mathrm{m}^{2}\right)$} & \multicolumn{3}{|c|}{ Number of weeds (no./m²) } \\
\hline & Graminoids & Forbs & Total & Graminoids & Forbs & Total \\
\hline \multicolumn{7}{|c|}{2013} \\
\hline T1 (MB:CP) & $43.6 b$ & $116.9 \mathrm{a}$ & $160.5 b$ & $1.8 \mathrm{~b}$ & $4.3 \mathrm{a}$ & $6.1 b$ \\
\hline $\mathrm{T} 2$ (1,3D:CP) & $238.8 \mathrm{a}$ & $206.6 \mathrm{a}$ & $445.4 \mathrm{a}$ & $9.6 \mathrm{ab}$ & $5.7 \mathrm{a}$ & $15.3 \mathrm{ab}$ \\
\hline $\mathrm{T} 3(\mathrm{CP})$ & $276.4 \mathrm{a}$ & $151.5 \mathrm{a}$ & $427.9 \mathrm{a}$ & $12.5 \mathrm{a}$ & $6.3 \mathrm{a}$ & $18.8 \mathrm{a}$ \\
\hline $\mathrm{T} 4$ (CP+MS) & $64.8 \mathrm{~b}$ & $89.8 \mathrm{a}$ & $154.6 b$ & $2.2 \mathrm{~b}$ & $5.2 \mathrm{a}$ & $7.4 \mathrm{ab}$ \\
\hline T5 (MS) & $193.5 \mathrm{ab}$ & $217.0 \mathrm{a}$ & $410.5 \mathrm{a}$ & $7.6 \mathrm{ab}$ & $4.6 \mathrm{a}$ & $12.2 \mathrm{ab}$ \\
\hline \multicolumn{7}{|c|}{2014} \\
\hline T0 untreat. & $679.1 \mathrm{a}$ & $652.6 \mathrm{ab}$ & $1331.7 \mathrm{a}$ & $18.5 \mathrm{a}$ & $17.9 \mathrm{~b}$ & $36.4 \mathrm{ab}$ \\
\hline T1 (MB:CP) & $6.1 \mathrm{c}$ & $393.9 \mathrm{ab}$ & $400.0 \mathrm{bc}$ & $0.3 b$ & $15.8 \mathrm{~b}$ & $16.1 \mathrm{~b}$ \\
\hline $\mathrm{T} 2$ (1,3D:CP) & $35.7 \mathrm{c}$ & $701.1 \mathrm{ab}$ & $736.8 \mathrm{abc}$ & $0.5 \mathrm{~b}$ & $46.5 \mathrm{a}$ & $47.0 \mathrm{a}$ \\
\hline $\mathrm{T} 3(\mathrm{CP})$ & $115.9 \mathrm{bc}$ & $119.9 \mathrm{~b}$ & $235.8 \mathrm{c}$ & $2.0 \mathrm{~b}$ & $8.0 \mathrm{~b}$ & $10.0 \mathrm{~b}$ \\
\hline T4 (CP+MS) & $91.7 \mathrm{c}$ & $895.5 \mathrm{a}$ & $987.2 \mathrm{abc}$ & $2.6 \mathrm{~b}$ & $45.5 \mathrm{a}$ & $48.1 \mathrm{a}$ \\
\hline T5 (MS) & $64.7 \mathrm{c}$ & $451.1 \mathrm{ab}$ & $515.8 \mathrm{abc}$ & $2.2 \mathrm{~b}$ & $12.7 \mathrm{~b}$ & $14.9 \mathrm{~b}$ \\
\hline T6 (DMDS:CP) & $509.7 \mathrm{ab}$ & $703.9 \mathrm{ab}$ & $1213.6 \mathrm{ab}$ & $8.0 \mathrm{~b}$ & $34.8 \mathrm{ab}$ & $42.8 \mathrm{a}$ \\
\hline
\end{tabular}

Treatments followed by the same letter withina column are not significantly different according to the LSD test $(P<0.05)$.

Table 5

Plant emergence and plant height in 2014

\begin{tabular}{|c|c|c|c|c|c|c|c|}
\hline \multirow[t]{2}{*}{ Treatment } & \multicolumn{3}{|c|}{$\begin{array}{c}\text { Plant emergence } \\
\text { (canes per lineal meter of bed) }\end{array}$} & \multicolumn{4}{|c|}{ Plant height $(\mathrm{cm})$} \\
\hline & April, 24 & May, 21 & June, 20 & April, 29 & June, 5 & July 29 & November, 28 \\
\hline T0 untreat. & $10.9 \mathrm{a}$ & $8.3 \mathrm{c}$ & $11.4 \mathrm{~d}$ & $15.0 \mathrm{a}$ & $37.5 \mathrm{c}$ & $121.9 \mathrm{~b}$ & $122.3 \mathrm{a}$ \\
\hline T1 (MB:CP) & $11.5 \mathrm{a}$ & $12.7 \mathrm{ab}$ & $14.7 \mathrm{abc}$ & $15.8 \mathrm{a}$ & $41.0 \mathrm{ab}$ & $136.5 \mathrm{a}$ & $131.8 \mathrm{a}$ \\
\hline $\mathrm{T} 2$ (1,3D:CP) & $11.3 \mathrm{a}$ & $13.5 \mathrm{a}$ & $16.0 \mathrm{ab}$ & $15.5 \mathrm{a}$ & $43.2 \mathrm{a}$ & $132.6 \mathrm{a}$ & $130.3 \mathrm{a}$ \\
\hline $\mathrm{T} 3(\mathrm{CP})$ & $10.7 \mathrm{a}$ & $11.9 \mathrm{ab}$ & $17.0 \mathrm{a}$ & $14.9 \mathrm{a}$ & $40.9 \mathrm{ab}$ & $130.4 \mathrm{a}$ & $129.0 \mathrm{a}$ \\
\hline $\mathrm{T} 4$ (CP+MS) & $9.3 \mathrm{a}$ & $10.3 b c$ & $13.4 \mathrm{~cd}$ & $16.5 \mathrm{a}$ & $39.8 b c$ & $131.9 \mathrm{a}$ & $127.9 \mathrm{a}$ \\
\hline T5 (MS) & $8.8 \mathrm{a}$ & $9.9 \mathrm{bc}$ & $15.5 \mathrm{abc}$ & $17.5 \mathrm{a}$ & $41.2 \mathrm{ab}$ & $130.0 \mathrm{a}$ & $128.5 \mathrm{a}$ \\
\hline T6(DMDS:CP) & $12.2 \mathrm{a}$ & 11.3abc & $13.9 \mathrm{bcd}$ & $16.4 \mathrm{a}$ & $40.7 \mathrm{abc}$ & $132.5 \mathrm{a}$ & $127.1 \mathrm{a}$ \\
\hline
\end{tabular}

Treatments followed by the same letter withina column are not significantly different according to the LSD test $(P<0.05)$.

$\mathrm{CP}+\mathrm{MS}$ but even after $\mathrm{CP}$ treatment forbs densities were similar to untreated check (Table 4). After treatments, forb species accounted for $72 \%$ and $84 \%$ (of the total fresh weight and weed number) in 2014 (Table 4). This suggests the weed population shift favouring forbs after soil fumigation and the need for effective tools for their management.

Plant emergence in May 2014 was 53\% greater, on average in T1 (BM:CP), T2 (1,3D:CP), T3 (CP) compared to untreated check (Table 5). In June 2014 these treatments and T5 (MS) had about 38\% more canes than in untreated check and these canes were about $10 \%$ taller. At the end of July plants in all fumigation treatments were significantly $(7-12 \%)$ taller than in untreated check (Table 5). This suggests beneficial effects of these fumigation treatments on plant growth and productivity. No significant effects were observed in 2013 (data not shown). 
Table 6

Commercially harvested raspberry root weights (cv. 'Driscoll Maravilla')

\begin{tabular}{lcc}
\hline Treatment & 2013 & 2014 \\
\cline { 2 - 3 } & \multicolumn{2}{c}{${\mathrm{kg} \cdot h \mathrm{~h}^{-1}}$} \\
\hline T0 untreat. & - & $1,272.4 \mathrm{c}$ \\
T1 (MB:CP) & $5,453.2 \mathrm{a}$ & $3,574.3 \mathrm{a}$ \\
T2 (1,3D:CP) & $4,569.1 \mathrm{ab}$ & $3,291.8 \mathrm{ab}$ \\
T3 (CP) & $3,730.1 \mathrm{~b}$ & $3,040.6 \mathrm{ab}$ \\
T4 (CP+MS) & $3,758,0 \mathrm{~b}$ & $2,756.4 \mathrm{~b}$ \\
T5 (MS) & $4,084.0 \mathrm{ab}$ & $2,659.1 \mathrm{~b}$ \\
T6 (DMDS:CP) & - & $2,990.9 \mathrm{ab}$ \\
\hline
\end{tabular}

Treatments followed by the same letter within Exp. column are not significantly different according to the LSD test $(P<0.05)$.

Commercial yields of raspberry roots (cv. 'Driscoll Maravilla') also showed clear benefits of soil fumigation. In 2014 root yields were 209 to $280 \%$ greater after fumigant treatments compared with no fumigation (Table 6). The highest root yields in experimental plots were observed after MB:CP and 1,3D:CP treatments in both years. These yield data are in agreement with plant emergence and height data (Table 5).

Finally, two years of work at one location on chemical MB alternatives were not sufficient to provide reliable recommendations on this critical need, therefore Methyl Bromide Technical Options Committee (MBTOC) [17] recommended MB for Critical Uses (CUN) for the Mexican Raspberry Nursery industry in 2015. It has been also suggested that on-farm trials are more important than trials on research stations for raspberry nursery production [18]. The highest priorities for the North American nursery operators were economic analysis of alternatives, followed by fumigation trials in commercial nurseries. Fumigant trials conducted on research stations and long-term (typically non-chemical) trials received lower priorities. Similarly, it has been emphasized that soil fumigation is a costly procedure that raspberry nurseries conduct to reduce the risk of even costlier events: inadvertently distributing plants contaminated with soilborne pathogens or nematodes (Walters, pers.com.). Thus, the efficacy of a soil fumigant is, overall, more important than its cost for the nursery production, but the choice of fumigant can significantly impact production costs. In a comparison of efficacy and economics of fumigants in raspberry nurseries in Washington and California 1,3D:CP in commercial formulations Telone C-35 and Pic-Clor 60 at the standard application rates were at least as effective as MB for pathogen and nematode control, and substantially less expensive (Walters, pers.com). Estimates of income based on root yield indicate that the non-fumigated controls performed well, primarily due to the savings in fumigation costs (Walters, pers.com.). However, without fumigation, the levels of pathogens Phytophthora rubi, Agrobacterium tumefaciens and Pratylenchus penetrans were significantly higher in untreated soil than in fumigated plots [19, 20]. Infestation with Pratylenchus penetrans alone could lead to an unmarketable crop [21] and pest populations are likely to increase over time without soil fumigation. Nevertheless, for different agro-environmental conditions such as central Mexico, it is necessary to continue on-farm evaluations of alternative fumigants for raspberry nurseries with focus on improved methods of application, evaluation of new alternative treatments with consideration of potential economic viability of these alternatives treatments. It is essential to carry out commercial field-scale demonstrations of most promising alternative fumigant treatments to facilitate technology transfer and adoption.

\section{Acknowledgments}

This study was supported a Pilot Project from The Mexican Government, through the Secretary of Environment and Natural Resources (SEMARNAT), in cooperation with the United Nations Industrial Development 
Organization (UNIDO) (2013-2014). The authors wish to thank to Driscoll's company and all their technical staff (Antonio Infante, Alfonso Begines, Araceli Rosales, Felipe Ruiz, Arturo Terrones and others) and workers in Ciudad Guzmán nurseries.

\section{References}

[1] López-Aranda JM, Soria C, Santos BM, Miranda L, Dominguez P, Medina-Mínguez JJ. Strawberry production in mild climates of the world: A review of current cultivar use. International Journal of Fruit Science. 2011;11(3):232-44. DOI: org/10.1080/15538362.2011. 608294

[2] Cotero MA, Urbina S, Estrada JF, Espinosa PI, Gómez F, Zamora ER, Castellá G, Soria C, López-Aranda JM. Demonstrations on MB Alternatives for Raspberry in Mexico. 2010-2013 Results. Proc Ann. Intl. Res. Conf. Methyl Bromide Alternatives and Emissions Reductions. San Diego, CA, 3-7 Nov. 2013: Available from http://www.mbao.org

[3] Pinkerton JN, Walters T, Schreiner RP, Miller T, Miller M, Littke W. Methyl bromide alternatives for red raspberry and forestry nurseries. Proc Ann Intl Res Conf. Methyl Bromide Alternatives and Emissions Reductions. San Diego, CA, 28 Oct.-1 Nov. 2007 : Available from http://www.mbao.org

[4] Walters T, Miller T, Particka M, Pinkerton JN, Zasada I. Methyl bromide alternatives for raspberry nurseries. Proc Ann Intl Res Conf. Methyl Bromide Alternatives and Emissions Reductions. Orlando FL, 10-13 Nov. 2008: Available from http://www.mbao.org

[5] UC IPM. Pest Management Guidelines-Caneberries. University of California, Agricultural and Natural Resources. UC Statewide Integrated Pest Management Program. Basler R, Gee RR and Laning RC, editors. Publication 3437. 2013; 59 pp. Available from http://www.ipm.ucdavis.edu/PDF/PMG/pmgcaneberries.pdf

[6] Ajwa HA, Klose S, Nelson SD, Minuto A, Gullino ML, Lamberti F, López-Aranda JM. Alternatives to methyl bromide in strawberry production in the United States of America and the Mediterranean region. 2003;42:220-44.

[7] Duniway JM. Status of chemical alternatives to methyl bromide for pre-plant fumigation of soil. Phytopathology. 2002;92(12):1337-43.

[8] López-Medina J, López-Aranda J M, Medina JJ, Miranda L, Dominguez F, Soria C, Vázquez-Ortiz E, Flores F. Strawberry production from transplants fumigated with methyl bromide alternatives. Span J Agric Res. 2007;5(3):407-16.

[9] López-Aranda JM. Methyl bromide alternatives (chemical and non-chemical) for strawberry cultivation in conventional areas of production. Acta Hort. 2014;1049:77-88.

[10] De Cal A, Martínez-Treceño A, López-Aranda JM, Melgarejo P. Chemical alternatives to methyl bromide in Spanish strawberry nurseries. Plant Disease. 2004;88(2):210-4.

[11] De Cal A, Martínez-Treceño A, Salto T, López-Aranda JM, Melgarejo and P. Effect of chemical fumigation on soil fungal communities in Spanish strawberry nurseries. Applied Soil Ecology. 2005;28:47-56.

[12] García-Méndez E, García-Sinovas D, Becerril M, De Cal A, Melgarejo P, Martínez-Treceño A, Fennimore S, Soria C, Medina JJ, López-Aranda JM. Chemical alternatives to methyl bromide for weed control and runner plant production in strawberry nurseries. Hort Science. 2008;43(1):177-82.

[13] García-Sinovas D, Andrade MA, Becerril M, De Cal A, Redondo C, Salto T, Medina JJ, Soria C, López-Aranda JM, Martínez-Treceño A. Soil disinfection in Spanish strawberry nurseries - Three years without methyl bromide. Acta Hort. 2014;1049:691-6.

[14] Jenkins WR. A rapid centrifugal-flotation technique for separating nematodes from soil. Plant Disease Reporter. 1964;48:692.

[15] Bolda M, Gaskell M, Mitcham E, Cahn M. Fresh Market Caneberry Production Manual. University of California. Agriculture and Natural Resources Publication 3525. 2012; 74 pp.

[16] USDA, NRCS. 2015. The PLANTS Database. Available from http://plants.usda.gov

[17] TEAP. Report of the Technology and Economic Assessment Panel. Volume 3, May 2014. Evaluation of 2014 Critical Use Nominations for Methyl Bromide. Interim Report; $57 \mathrm{pp.}$

[18] McMoran D, Walters T, Zasada I. Top ten things to know about methyl bromide: A raspberry nursery survey. Proc Ann. Intl. Res. Conf. Methyl Bromide Alternatives and Emissions Reductions. Orlando FL, 1-5 Nov. 2010: Available from http://www.mbao.org

[19] Zasada I, Pinkerton JN, Walters T, Particka M. Methyl bromide alternatives trials in raspberry nurseries. Proc Ann. Intl. Res. Conf. Methyl Bromide Alternatives and Emissions Reductions. Orlando FL, 1-5 Nov. 2010a: Available from http://www.mbao.org

[20] Zasada IA, Walters TW, Hanson BD. Challenges in producing nematode- and pathogen-free fruit and nut nursery crops in the United States. Outlooks on Pest Management. 2010b, 246-50.

[21] Carpenter J. The importance of soil fumigation: Nursery crops. CropLife Foundation, Crop Protection Research Institute. 2013; 10 pp: Available from http://www.croplifefoundation.org 